\title{
Acta
Biochimica
Polonica
}

Vol. 51 No. 1/2004

$67-72$

QUARTERLY

\section{New analogue of cyclolinopeptide B modified by amphiphilic residue of $\alpha$-hydroxymethylmethionine ${ }^{\star \star}$}

\author{
Renata Witkowska ${ }^{1}$, Anna Donigiewicz ${ }^{2}$, Michał Zimecki ${ }^{2}$ and Janusz Zabrocki ${ }^{1 凶}$ \\ ${ }^{1}$ Institute of Organic Chemistry, Technical University of Łódź, Łódź, Poland; ${ }^{2}$ Institute of \\ Immunology and Experimental Therapy, Polish Academy of Sciences, Wroctaw, Poland
}

Received: 31 October, 2003; revised: 27 January, 2004; accepted: 08 Fabruary, 2004

Key words: analogue of cyclolinopeptide B, $\alpha$-hydroksymethylamino acids, $\alpha$-hydroksymethylmethionine

\begin{abstract}
In order to evaluate the role and influence of the methionine residue on the biological activity of cyclolinopeptide $B$, an analogue with methionine residue in position 7 replaced by the amphiphilic $(S)$ - $\alpha$-hydroxymethylmethionine residue was synthesized. This peptide exhibits high immunosuppressive activity in the cellular, and to a lesser degree in the humoral immune response, comparable to that of CsA. In addition, the peptide was devoid of toxicity, even at high doses.
\end{abstract}

The use of cyclosporine A (CsA) and FK-506 in transplantology is limited by their side-effects (Soy et al., 1995; Hojo et al., 1999). The search for new immunosuppressants, exhibiting a similar mechanism of action but devoid of toxicity, especially in the group of natural immunomodulatory peptides and their ana- logues, is an important challenge for medicinal chemistry.

Cyclolinopeptide B (CLB), a natural cyclic nonapeptide cyclo(-Pro-Pro-Phe-Phe-Val-IleMet-Leu-Ile-), was isolated together with the very similar CLA cyclo(Pro-Pro-Phe-PheLeu-Ile-Ile-Leu-Val) from seeds of Linum

\footnotetext{
${ }^{\star}$ Presented at the 17th Polish Peptide Symposium, August 31st-September 4th, 2003, Łódź, Poland.

This work was partially supported by the State Committee for Scientific Research (KBN, Poland), Grant No. 7 T09A 09321.

${ }^{\square}$ Corresponding author: Janusz Zabrocki, Institute of Organic Chemistry, Technical University of Łódź, 90-924 Łódź, Poland; phone: (48 42) 631 3153; fax (48 42) 636 5530; e-mail: zabrocki@p.lodz.pl

Abbreviations: Boc, tert-butyloxycarbonyl; $\mathrm{Boc}_{2} \mathrm{O}$, tert-butyloxycarbonyl anhydride; CLB, cyclolinopeptide B; CsA, cyclosporine A; DIEA, diisopropylethylamine; $\alpha$-HmM, $\alpha$-hydroxymethylmethionine; HF, hydrogen fluoride; HPLC, high performance liquid chromatography; MALDI, Matrix-assisted laser desorption ionisation; OVA, ovalbumin, PFC, plaque forming cells; SRBC, sheep red blood cells; DTH, delayed type hypersensitivity, TBTU, $O$-(benzotriazol-1-yl)- $N, N, N^{\prime}, N^{\prime}$-tetramethyluronium tetrafluoroborate; TFA, trifluoroacetic acid; TLC, thin layer chromatography; $\mathrm{TMAH} \times 5 \mathrm{H}_{2} \mathrm{O}$, tetramethylammonium hydroxide pentahydrate.
} 
usitatissimum (Linaceae) in 1959 (Kaufman \& Tobschirbel, 1959). Sequence analysis of both peptides was performed by Prox and Weygand (Prox \& Weygand, 1967; Weygand, 1968) and the CLB sequence was additionally supported by Morita et al. in 1997 (Morita et $a l .$, 1997). This peptide reveals an inhibitory effect on a mitogen (concanavalin A), comparable to that of cyclosporin A (Morita et al., 1999). The three-dimensional structure of CLB (Fig. 1) was established by Takeya et al.

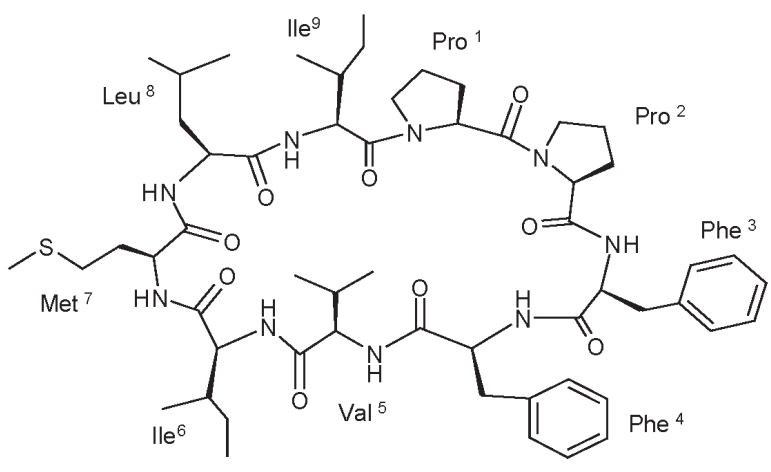

Figure 1. Structure of cyclolinopeptide B.

(Morita et al., 1999; Matsumoto et al., 2002) showing similarity to the known CLA structure with a cis amide bond between two proline residues. A recent report by Picur et al. (2002) has shown that natural CLB can adopt two different structural forms with opposite thermal effects concluded, from their CD and NMR spectra.

In this paper we describe the synthesis of an analogue of CLB with the methionine residue in position 7 replaced by the amphiphilic (S)- $\alpha$-hydroxymethylmethionine in order to evaluate the role of methionine residue and the influence of the hydrophilic hydroxymethyl group on the peptide biological activity. It is worth to note that (S)- $\alpha$-hydroxymethylmethionine might be considered as a hybrid of two amino acids, serine and methionine.

\section{MATERIALS AND METHODS}

\section{Chemistry}

Racemic $\alpha$-hydroxymethylmethionine was synthesized by selective $\alpha$-hydroxymetylation, and resolved into enantiomers by fractional crystallization of diastereomeric salts of their N-benzoyl derivatives with (-)-quinine, using the method previously described (Witkowska et al., 2001). (S)-Boc-HmM was prepared according to published procedure (Khalil et al., 1996) in acetonitrile using $\mathrm{TMAH} \times 5 \mathrm{H}_{2} \mathrm{O}$ and $\mathrm{Boc}_{2} \mathrm{O}$.

The peptide was synthesized by the manual solid-phase method using Boc-Val-Merrifield resin (200-400 mesh, $0.59 \mathrm{mmole} / \mathrm{g}$, Novabiochem). $\mathrm{N}^{\alpha}$-Boc-protected amino acids were obtained from commercial sources. Starting with $0.68 \mathrm{~g}(0.4 \mathrm{mmol})$ of resin the following protected amino acids were added in a stepwise fashion to the growing peptide chain: $\mathrm{N}^{\alpha}$-Boc-Phe, $\mathrm{N}^{\alpha}$-Boc-Phe, $\mathrm{N}^{\alpha}$-Boc-Pro, $\mathrm{N}^{\alpha}$-Boc-Pro, $\mathrm{N}^{\alpha}$-Boc-Ile, $\mathrm{N}^{\alpha}$-Boc-Leu, $\mathrm{N}^{\alpha}$-Boc$(S)-H m M, \mathrm{~N}^{\alpha}$-Boc-Ile. The amino acids were coupled in 3-fold excess using TBTU (3 equiv.) in the presence of DIEA (6 equiv.). When $\alpha$-hydroxymethylamino acid was acylated or used as an acylating component, prolonged reaction times (24 $\mathrm{h}$ for repeated coupling) was necessary. Removal of the Boc protecting group was performed with $50 \%(\mathrm{v} / \mathrm{v}) \mathrm{TFA}$ in $\mathrm{CH}_{2} \mathrm{Cl}_{2}$ for 5 and $20 \mathrm{~min}$, followed by $\mathrm{CH}_{2} \mathrm{Cl}_{2}$ washes ( $3 \times 1 \mathrm{~min})$, a neutralization with $10 \%$ DIEA in $\mathrm{CH}_{2} \mathrm{Cl}_{2}$ for 5 and $10 \mathrm{~min}$ and $\mathrm{CH}_{2} \mathrm{Cl}_{2}$ washes $(3 \times 1 \mathrm{~min})$. Completion of coupling reactions was monitored by the ninhydrin test (Kaiser et al., 1970). The linear peptide was cleaved from the resin using anhydrous $\mathrm{HF}$ ( $5 \mathrm{ml} / \mathrm{g}$ resin) procedure with anisole added as a scavenger $(1 \mathrm{ml} / \mathrm{g}$ resin) for $1 \mathrm{~h}$ at $0^{\circ} \mathrm{C}$. After evaporation of $\mathrm{HF}$, the resin was extracted three times with anhydrous ethyl ether and, subsequently with $50 \%$ aqueous solution of acetic acid. The crude linear peptide was obtained in solid form by lyophilization of the acetic acid extracts and was purified by 
preparative reversed-phase HPLC on a Vydac $\mathrm{C}_{18}$ column $(25 \times 2.2 \mathrm{~cm})$ with a linear gradient $40-80 \% \mathrm{~B}$ at a flow rate $12 \mathrm{ml} / \mathrm{min}$. The linear peptide was cyclized by means of TBTU reagent. The cyclic peptide was $>99 \%$ pure as determined by analytical reversed-phase HPLC on a Vydac $\mathrm{C}_{18}$ column $(25 \times 0.46 \mathrm{~cm})$ using a linear gradient of $40-80 \% \mathrm{~B}$ in $25 \mathrm{~min}$ at a flow rate of $1 \mathrm{ml} / \mathrm{min}$, with UV detection at $220 \mathrm{~nm}$. The relative molecular mass $\left(M_{\mathrm{r}}\right)$ was confirmed by MALDI-TOF MS. Analytical data of the linear and cyclic analogues are presented in Table 1. tracting the foot pad thickness of naïve mice given the eliciting dose of the antigen from the DTH reaction of sensitised mice.

Determination of the effect of the peptides on the inductive and effector phase of DTHG response. To establish the effect of the peptides on the inductive phase of the DTH response (events leading to generation of antigen-specific T cells, such as antigen processing and presentation) the compounds were given $2 \mathrm{~h}$ before and $24 \mathrm{~h}$ after immunization. In order to evaluate the influence of the peptides on the effector phase of

Table 1. Analytical data of linear and cyclic $\left[(S)-\mathrm{HmM}^{7}\right] \mathrm{CLB}$

\begin{tabular}{llllcc}
\hline Compound & Total formula & $M_{\mathrm{r}}$ & MALDI & HPLC $_{\mathrm{R}}{ }^{\mathrm{a}}(\min )$ & $\mathrm{TLC} R_{\mathrm{f}}^{\mathrm{b}}$ \\
\hline $\begin{array}{l}\text { linear } \\
{\left[(S)-\mathrm{HmM}{ }^{7}\right] \mathrm{CLB}}\end{array}$ & $\mathrm{C}_{57} \mathrm{H}_{87} \mathrm{O}_{11} \mathrm{~N}_{9} \mathrm{~S}$ & 1106.4 & 1107 & 13.20 & 0.50 \\
$\begin{array}{l}\text { cyclic } \\
{\left[(S)-\mathrm{HmM}{ }^{7}\right] \mathrm{CLB}}\end{array}$ & $\mathrm{C}_{57} \mathrm{H}_{85} \mathrm{O}_{10} \mathrm{~N}_{9} \mathrm{~S}$ & 1088.4 & 1089 & 19.71 & 0.91 \\
\hline
\end{tabular}

${ }^{a}$ Linear gradient of $20-50 \%$ B over $25 \mathrm{~min}$ at a flow rate of $1 \mathrm{ml} / \mathrm{min}$; (A) $0.05 \%$ trifluoroacetic acid in water and (B) $0.038 \%$ trifluoroacetic acid in acetonitrile/ $\mathrm{H}_{2} \mathrm{O}(90: 10, \mathrm{v} / \mathrm{v}) ;{ }^{b} \mathrm{n}-\mathrm{BuOH} / \mathrm{AcOH} / \mathrm{AcOEt} / \mathrm{H}_{2} \mathrm{O}(1: 1: 1: 1$, by vol.)

\section{Biology}

Effects of the peptide on the induction phase and the effector phase of the delayed type hypersensitivity (DTH) in CBA mice as well as the effects of the peptide on the induction phase of the humoral immune response to sheep red blood cells (SRBC) were examined.

Animals. CBA mice (males and females, 10-12 weeks old) were delivered by the Animal Facility of the Institute of Immunology and Experimental Therapy, Wrocław, Poland. Mice were fed commercial, pelleted food and water ad libitum.

Generation of the cellular immune response to ovalbumin (OVA). Mice were immunized subcutaneously (s.c.) into tail base with $5 \mu \mathrm{g}$ OVA in complete Freund's adjuvant (cFa). After 4 days the DTH reaction was elicited by s.c. injection of $50 \mu \mathrm{g}$ OVA in incomplete Freund's adjuvant (iFa) into hind feet. Specific DTH reaction was calculated by sub- the DTH reaction (administration of an eliciting dose of antigen leading to attraction of already existing antigen-specific $\mathrm{T}$ cells and accompanying cells (neutrophils and macrophages to the site of antigen depot), the compounds were given i.p. $2 \mathrm{~h}$ before the eliciting dose of the antigen.

Reagents. SRBC were supplied by the Laboratory of General Chemistry, Institute of Immunology. SRBC were stored in Alsever's solution for at least 3-4 days before use. Cyclosporine A (CsA) was purchased from Sandoz (Switzerland) and ovalbumin from Sigma. For application in mice CsA, dissolved in a commercial solvent (Cremophor), was further diluted in saline.

Immunization of mice for studies of humoral immune response and determination of plaque forming cells. CBA mice were immunized intraperitoneally (i.p.) with a single $0.2 \mathrm{ml}$ dose of $5 \% \mathrm{SRBC}$ suspension 
Table 2. Effects of $\left[(S)-\mathrm{HmM}^{7}\right] \mathrm{CLB}$ on the induction phase of the delayed type hypersensitivity (DTH) in CBA mice

\begin{tabular}{lcllll}
\hline Compound & Dose $(\mu \mathrm{g} /$ mouse $)$ & DTH Units & Iinhibition (\%) & \pm S.E. & $P$ Student's test \\
\hline Control & & 17.1 & & & \\
& 10 & 5.6 & 67 & 0.37 & $<0.001$ \\
{$\left[(S)-\mathrm{HmM}^{7}\right] \mathrm{CLB}$} & 100 & 4.9 & 71 & 0.27 & $<0.001$ \\
& 10 & 5.6 & 67 & 0.25 & $<0.001$ \\
CsA & 100 & 2.5 & 85 & 0.18 & $<0.001$ \\
\hline
\end{tabular}

The preparations were given intraperitoneally $2 \mathrm{~h}$ before and $24 \mathrm{~h}$ after the sensitizing dose of antigen (OVA).

Table 3. Effects of $\left[(S)-\mathrm{HmM}^{7}\right] \mathrm{CLB}$ on the effector phase of the delayed type hypersensitivity (DTH) in CBA mice

\begin{tabular}{llllll}
\hline Compound & Dose $(\mu \mathrm{g} /$ mouse $)$ & DTH Units & Inhibition (\%) & \pm S.E. & $P$ Student's test \\
\hline Control & & 9.1 & & & \\
{$\left[(S)-\mathrm{HmM}^{7}\right] \mathrm{CLB}$} & 20 & 6.3 & 30 & 0.32 & $<0.001$ \\
& 200 & 5.1 & 44 & 0.32 & $<0.001$ \\
\hline
\end{tabular}

The preparation was given intraperitoneally $2 \mathrm{~h}$ before the eliciting dose of antigen.

Table 4. Effects of $\left[(S)-\mathrm{HmM}^{7}\right] \mathrm{CLB}$ on the induction phase of the humoral immune response to sheep red blood cells (SRBC).

\begin{tabular}{lcllll}
\hline Compound & Dose $(\mu \mathrm{g} /$ mouse $)$ & $\mathrm{PFC} / 10^{6}$ & Percent of control & \pm S.E. & $P$ Student's test \\
\hline Control & & 1589 & & & \\
{$\left[(S)-\mathrm{HmM}^{7}\right] \mathrm{CLB}$} & 10 & 1411 & 89 & 30.69 & $<0.02$ \\
& 100 & 1476 & 93 & 59.17 & $\mathrm{NS}$ \\
\multirow{2}{*}{$\mathrm{CsA}$} & 10 & 1564 & 98 & 16.39 & $\mathrm{NS}$ \\
& 100 & 1310 & 82 & 35.59 & $<0.01$ \\
\hline
\end{tabular}

The preparations were given intraperitoneally $2 \mathrm{~h}$ before and $24 \mathrm{~h}$ after immunization of mice with SRBC.

in $0.9 \%$ saline. After 4 days the spleens were isolated, single cell suspension was prepared and the number of plaque forming cells (PFC) was determined according to Mishell and Dutton (1967) and expressed as the PFC number per $10^{6}$ viable spleen cells.

\section{Statistics}

For evaluation of data the Student's test was applied. The studied groups of mice consisted of 5 mice. The results are presented as mean values from 5 mice (humoral immune response) and 10 determinations (two hind foot pads - from 5 mice): DTH \pm standard error (S.E.). The results were considered significant when $P<0.05$.

\section{RESULTS AND DISCUSSION}

$\left[(S)-\mathrm{HmM}^{7}\right] \mathrm{CLB}$ strongly inhibited the magnitude of the delayed type hypersensitivity response (Table 2). CsA, a reference drug, was 
Table 5. Mice mortality after immunization

\begin{tabular}{lcl}
\hline Compound & Dose $(\mu \mathrm{g} /$ mouse $)$ & Mice mortality (\%) \\
\hline Control & & 0 \\
& 50 & 0 \\
{$\left[(S)-\mathrm{HmM}^{7}\right] \mathrm{CLB}$} & 500 & 0 \\
& 50 & 0 \\
$\mathrm{CsA}$ & 500 & 12.5 \\
\hline
\end{tabular}

The compounds were given i.p. into mice at the indicated doses. The mice were monitored for signs of toxicity and for mortality for 10 days. Eight mice per group were used.

also a strong inhibitor showing a dose dependent effect. As far as the effector phase of DTH was concerned, the peptide exhibited statistically significant inhibition of the DTH reaction $(P<0.001)$, although to a lesser degree as compared to the effects exerted on the inductive phase of DTH (Table 3). CsA was not used in this case because previous studies showed no effect of CsA on the effector phase of DTH. The effect of the peptide on the inductive phase of the humoral immune response was comparable to that of CsA (Table 4), but was minor and significant only at the dose of $10 \mu \mathrm{g} / \mathrm{mouse}$. Interestingly the synthesized analogue of CLB modified by (S)-HmM demonstrated no toxicity (Table 5) even in high doses. These results encourage us to continue the project on construction and synthesis of a new analogues of CLB in the hope of obtaining potent immunosuppressants showing no side-effects. The latter is particularly relevant in the light of the recently reported carcinogenic properties of CsA via the cell-autonomous mechanism (Hojo et al., 1999).

\section{R E F E R E N C E S}

Hojo M, Morimoto T, Maluccio M, Asano T, Morimoto K, Lagman M, Shimbo T, Suthanthiran M. (1999) Cyclosporine induces cancer progression by a cell autonomous mechanism. Nature.; 397: 530-4.
Kaiser E, Colescott RL, Bossinger CD, Cook PI. (1970) Color test for detection of free terminal amino group in the solid-phase synthesis of peptides. Anal Biochem.; 34: 595-8.

Kaufman HP, Tobschirbel A. (1959) Über ein Oligopeptid aus Leinsamen. Chem Ber.; 92: 2805-9.

Khalil EM, Subasinghe NL, Johnson RL. (1996) An efficient and high yield method for the $N$-tert-butoxycarbonyl protection of sterically hindered amino acids. Tetrahedron Lett.; 37: 3441-4.

Matsumoto T, Shishido AT, Morita H, Itokawa H, Takeya K. (2002) Conformational analysis of cyclolinopeptides A and B. Tetrahedron.; 58: $5135-40$.

Mishell RI, Dutton RW. (1967) Immunization of dissociated spleen cell cultures from normal mice. J Exp Med.; 126: 423-42.

Morita H, Shishido A, Takeya K, Itokawa H, Hirano T, Oka K, Shirota O. (1997) A new immunosuppressive cyclic nonapeptide cyclolinopeptide B from Linum usitatissimum. Bioorg Med Chem Lett.; 7: 1269-72.

Morita H, Shishido A, Matsumoto T, Itokawa H, Takeya K. (1999) Cyclolinopeptides B-E, new cyclic peptides from Linum usitatissimum. Tetrahedron.; 55: 967-76.

Picur B, Brzezicka A, Chliszcz P, Cebrat M, Lisowski M, Olejarnik M, Ruchała P, Śpiewak K, Siemion IZ. (2002) Cyclic peptides from different flaxes. In Peptides 2002, Proc. 27th Eur. Peptide Symposium, Bennedetti E, Pedone C, eds, pp 396-7, Edizioni Ziino, Napoli. 
Prox A, Weygand F. (1967) Sequenzanalyse von Peptiden durch Kombination von Gaschromatographie und Massenspektrometrie. In Peptides 1966, Proc. 8th Eur. Peptide Symposium, Bayerman $\mathrm{HC}$ van den Linde A, Massen van den Bring W, eds, pp 158-72. North-Holland Publishing Co, Amsterdam.

Soy D, Campistol JM, Brunet M, Roca M, Carreras E, Andreu H, Codina C, Ribas J. (1995) Role of cyclosporine metabolites and chemical toxicity in organ transplantation. Transplant Proc.; 27: 2415-6.

Weygand F. (1968) Entwicklunglinien Biochemischer Analytik. Z Anal Chem.; 243: 2-17.

Witkowska R, Kaczmarek K, Crisma M, Toniolo C, Zabrocki J. (2001) $\mathrm{C}^{\alpha}$-Hydroxymethyl methionine: synthesis, optical resolution and crystal structure of its (+)- $\mathrm{N}^{\alpha}$-benzoyl derivative. J Peptide Sci.; 7: 619-25. 